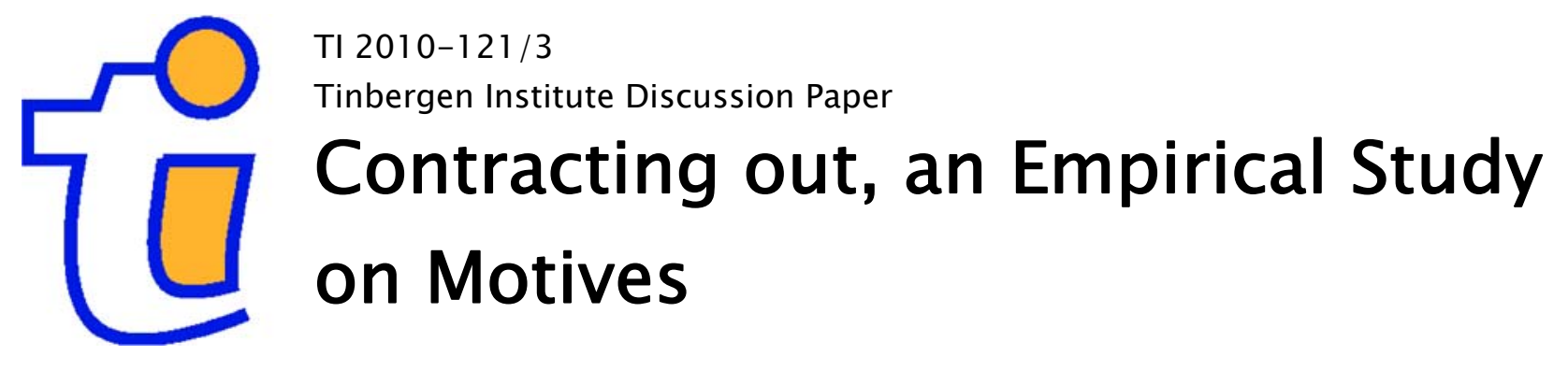

\author{
Mattheus Wassenaar \\ Tom Groot** \\ Raymond Gradus ${ }^{* * * *}$
}

"Ministry of Social Affairs and Employment, and VU University Amsterdam, Faculty of Economics and Business Administration;

**) VU University Amsterdam, Faculty of Economics and Business Administration;

***) VU University Amsterdam, Faculty of Economics and Business Administration, Tinbergen Institute. 


\section{Tinbergen Institute}

The Tinbergen Institute is the institute for economic research of the Erasmus Universiteit Rotterdam, Universiteit van Amsterdam, and Vrije Universiteit Amsterdam.

Tinbergen Institute Amsterdam

Roetersstraat 31

1018 WB Amsterdam

The Netherlands

Tel.: +31(0)205513500

Fax: $+31(0) 205513555$

Tinbergen Institute Rotterdam

Burg. Oudlaan 50

3062 PA Rotterdam

The Netherlands

Tel.: + $31(0) 104088900$

Fax: $+31(0) 104089031$

Most TI discussion papers can be downloaded at http://www.tinbergen.nl. 


\title{
Contracting out, an empirical study on motives ${ }^{1}$
}

\author{
Mattheus Wassenaar ${ }^{*}$, Tom Groot $^{* *}$, Raymond Gradus ${ }^{* * *}$
}

Keywords: Contracting out, municipalities, institutional theory, motives

\begin{abstract}
Municipalities may have various motives for decisions on the mode of their task execution. Empirical studies - based on both public choice and transaction costs theory have not yet provided a fully comprehensive explanation for municipal contracting out decisions. Therefore, we held interviews with Dutch municipal managers about the motives for the actual mode of service provision. This study provided the opportunity to investigate the relevance of motives on contracting out, to explore of additional motives and to test these statistically. As we find, municipalities do not regularly evaluate the service provision of their activities. Only in case of structural underperformance, municipalities consider a change of service provider, and then, the efficiency motive is most relevant. However, we conclude that institutional motives - as the stability of service provision - are relevant for contracting out decisions as well.
\end{abstract}

\footnotetext{
${ }^{*)}$ Ministry of Social Affairs and Employment and VU University Amsterdam, Faculty of Economic Science

De Boelelaan 1105

1081 HV Amsterdam, The Netherlands

0031-6-43457651,m.wassenaar@tiscali.nl

${ }^{* *}$ VU University Amsterdam. Faculty of Economic Science

${ }^{* * *)}$ VU University Amsterdam, Faculty of Economic Science and Tinbergen Institute
}

\footnotetext{
${ }^{1}$ We thank Jan Verhagen, Municipality of The Hague, Rien Fraanje, Council for Public Management, before affiliated with Bureau Berenschot, and Ard Schilder, BMC consultants, for advice on the interview protocol. Maarten Allers provided useful comments on a previous version of this paper.
} 


\section{Introduction}

A broad range of studies show the benefits of contracting out as competition for contracts can increase efficiency of public activities such as refuse collection and cleaning services (Domberger and Jensen, 1997; Tang, 1997). Other benefits, as the quality of private service provision, may be relevant as well. However, the European VAT (Value Added Tax) system favours public provision over contracting out to the private sector. Contracting out leads - despite the potential cost-efficiency - to higher gross costs for governments, as the net costs of the service are raised by VAT. Therefore, public authorities cannot make an optimal decision to achieve efficiency gains or for nonbudgetary considerations. As in northern European countries, the Dutch government in 2003 introduced a refund scheme to address this distortion (Wassenaar and Gradus, 2004). However, as Wassenaar et al. (2010) show, this did not lead to a significant change in contracting out.

This paper explores the motives of Dutch municipalities in favour or against contracting out their activities to public or private external service providers and contributes to the literature in two ways. First, we provide an analysis of motives for contracting out decisions for municipalities, by interviewing the responsible managers. The second innovative aspect is that we include an explorative search for the relevance of institutional and pragmatic motives in contracting out decisions, in addition to the more common public choice and transaction costs approaches.

This paper is structured as follows. Section 2 describes the theoretical motives for public authorities for contracting out their activities. Section 3 describes the research questions of this study and section 4 presents the survey methodology we use. Section 5 discusses the results of the interviews, while section 6 discusses these results with respect to the empirical literature ending with concluding remarks.

\section{Motives for contracting out}

Municipalities may have various reasons to contract out their service delivery to the private sector. Private contractors possess advantages over public organisations as they have a stronger focus on results due to the competition among suppliers, the necessity to earn at least an average return on investment, a more flexible labour force, fewer procedural constraints and more powerful structure of incentives for managers (Hart et al., 1997; Shleifer, 1998). Besides, private companies can profit from economies of scale as they can distribute their fixed costs over more than one municipality. Some of these advantages are valid for public organisations such as inter-municipal corporations as well, as they achieve similar results by creating a market for service provision beyond a single jurisdiction (Dijkgraaf and Gradus, 2003). 
Many studies find support for the efficiency claims for contracting out public activities such as refuse collection, fire protection and cleaning services. Overview studies (e.g. Domberger and Jensen, 1997; Tang, 1997) indicated cost savings of about twenty percent, without sacrificing the quality of services provided. However, other reviews of empirical literature suggested that the support for the efficiency claim is at best mixed (Boyne, 1998a; Hodge, 2000). Recently, Bel and Warner (2008) concluded that no direct and systematic relationship can be established between savings or productivity gains and private production.

A second prominent benefit of outsourcing is the higher quality of private production (Brudney et al., 2004). However, the effect of contracting out on service quality remains largely unknown, as only a few empirical studies have been conducted on this issue. In a meta-analysis (Hodge, 2000), the effect of contracting out on service quality was statistically indistinguishable from zero.

\section{Differences in contracting out}

Despite the potential benefits of contracting out, local governments differ in the extent to which they outsource their activities. A number of theories are used to explain the municipal considerations for contracting out. Public choice theory focuses on the public organisation and the behaviour of managers, and is useful to investigate the reasons for municipalities to transfer a part of their production to the private sector. Transaction costs theory is especially useful for understanding the reasons why certain activities are contracted out, while other services are provided by the municipalities themselves. However, despite a broad range of empirical studies based on both theories, a comprehensive explanation for the contracting out behaviour of municipalities is still lacking (Bel and Fageda, 2007). Neo-institutional literature postulates theories on the dynamics of organisations. However, this literature has not been tested empirically on the aspect of contracting out.

Most studies on contracting out behaviour of public organisations are based on public choice theory (Bel and Fageda, 2007). This theory focuses on the political motivations behind managerial decisions. Public managers are credited as self-interested agents who try to maximise their personal utility and interest through longer terms or larger budgets (Niskanen, 1971). Therefore, they will monopolise public service delivery leading to a sub-optimal level of production and inefficiency. The remedy for this behaviour is competition in markets for public services. Consequently, contracting out should lead to lower costs and higher technical efficiency. 
Public choice theory leads to three hypotheses about the municipal decision-making on the contracting out of public services (Lopez-de-Silanes, et al., 1997; Bel et al., 2007). ${ }^{2}$

1. Efficiency. Cost reduction may be an important objective of contracting out, to be realised through competition and the exploitation of scale economies. Smaller municipalities may profit from contracting out via scale advantages by the aggregation of the demands of more than one municipality by a private company. Besides, the potential for cost reduction may be higher in larger and urban areas where more private providers are available as this increases the potential for competition (Warner and Hefetz, 2002; Hebdon and Jalette, 2008).

2. Political patronage. Contracting out decisions may be dependent of pressure groups having a particular interest in the rents from a specific type of service delivery. Hence, a high level of unionisation has been negatively linked to privatisation. On the other hand, strong industrial interests should lead to privatisation.

3. Ideology. As voters have preferences on the role of government, ideology may influence privatisation discussions. Left-wing governments will be more reluctant to privatise local services, in contrast with right-wing governments, as they are more pro-private business values, whereas left-wing parties are conventionally associated with public values.

Lopez-de-Silanes et al. (1997), based on data for 12 sectors for nearly all UScountries, showed the importance of political factors for the decision whether public services are contracted out. It seems that US-politicians derive significant benefits from in-house provision of public services - such as support from public employee unions and possibilities to influence unemployment through public payrolls - they would lose in case of privatisation.

In a study on municipal refuse collection in the Netherlands, using panel data for all Dutch municipalities, Dijkgraaf et al. (2003) found evidence that relatively high grants from the central government (the efficiency motive, as a higher transfers might diminish the emphasis on cost savings) or a high level of unemployment (the political patronage motive) raises the probability of contracting out. Moreover, smaller municipalities are more likely to choose a private waste collector due to scale economies. Ideological factors seem to play a minor role. Bel and Miralles (2003) concluded in a study based on the privatisation of waste collection, that Spanish municipalities are led by pragmatic rather than ideological reasons. Warner and Hebdon (2001) showed that local

\footnotetext{
${ }^{2}$ A fourth hypothesis is that fiscal stress should lead to more privatisation. In the last decades, fiscal restrictions were introduced to reduce the ability to raise the local tax revenues in countries like the United States. Because in the Netherlands these fiscal constraints are not applied, we will not investigate this fourth hypothesis in this study.
} 
governments are more concerned with practical issues of service quality, and less with ideology, politics and unionisation. Pragmatism wins out over politics as local governments give a keen eye to market structure, service quality and efficiency concerns.

In a meta-study, Bel and Fageda (2007) analysed 28 multivariate studies from six countries on local privatisation. They found that fiscal stress and interest group pressures influenced the privatisation of local services in early US-studies that considered a broader range of services. Interest groups have their influence, particularly for smaller municipalities in small towns. Cost considerations are especially relevant when the exploitation of scale economies is taken together with privatisation choices. However, the ideological attitudes of policy makers do not seem to influence the service delivery choice of local governments in a systematic way. Finally, the authors concluded that local government decisions appear to be more pragmatic than ideological.

However, Bel and Fageda (2007) concluded that the explanatory power of these empirical studies is, in general, low. One explanation is that most studies do not analyse the privatisation decision in year $\mathrm{t}-\mathrm{x}$ (the move from public to private) but use the actual production form in year $t$ as a dependent variable. Therefore, these studies are based on a mis-specified model, as the dependent variable does not measure a dynamic choice of service production technology but rather the current status of service production (Boyne, 1998b). Since then, factors testing for the actual mode of service provision might have changed completely, while the production mode is still in accordance with the factors that were applicable when the decision was made. Another explanation is that local governments have limited capability to make discretional decisions about the production form after the years privatisation has been implemented, due to for example the duration of contracts or difficulties of re-internalising production. Therefore, the decision for contracting out is path-dependent.

\section{Transaction costs}

Despite the potential efficiency of the private sector, the process of contracting out comes with transaction costs: 'the comparative costs of planning, adapting, and monitoring task completion under alternative governance structures' (Williamson, 1981). From this perspective, privatisation can only deliver cost savings whenever they surpass the transaction costs (Bel and Fageda, 2007).

Williamson (1981) focused on two broad service-specific characteristics being relevant for the transaction costs, asset specificity and service measurability. Asset specificity refers to whether specialized investments are required to produce the service. These assets apply to the production of one service but are very difficult or at high costs to adapt for the production of other services and offer an advantage to the first contract winner, thus creating a barrier to entry. Service measurability refers to the difficulties for 
the contracting organization to measure the outcomes of the service or to monitor the activities required to deliver the service. Contracting out is likely to be more successful if the magnitude and the specificity of the assets required to provide the service are smaller, the quality characteristics that are non-contractible are less important and competitive supply in the market, both actual and potential, is large (Domberger and Jensen, 1997).

In a US-study on 64 types of municipal activities, Brown and Potoski (2005) supposed a relationship between the contracting out decisions of municipalities and the potential transaction costs due to the asset specificity and the measurability of services. However, a statistical analysis on this hypothesis is lacking in this study. Brown et al. (2008) showed that both service measurability and asset specificity influence the service delivery choices.

\section{Neo-institutional literature}

Neo-institutional literature describes that economically rational considerations do not fully explain the behaviour of public organizations. Institutional factors - as rules, values, habits, power, and internal and external pressure - all influence change processes in organizations (Lounsbury, 2008; Modell, 2009; Scott, 2008; Ter Bogt, 2008). In this literature, it is assumed that a primary determinant of organizational structure is the pressure exerted by external and internal constituencies on the organization, to conform with a set of expectations to gain legitimacy and so secure access to vital resources and long-term survival. Therefore, the primary objective of organizational change is not a better performance but greater legitimacy. Organizations adapt in order to conform to the expectations of the key stakeholders (Brigall and Modell, 2000; Ashworth et al., 2007).

Oliver (1992) identified three sources of pressure on institutional norms or practices leading to institutional change: functional, political and social. Functional pressures for de-institutionalisation are those that arise from perceived problems in performance levels or the perceived utility associated with organizational practices. Political pressures arise when the utility or legitimacy of current practices is seriously called into action. Social pressures arise from the environment of the organisation, as disruptions to the organisations historical continuity or changes in law or societal expectations (Dacin et al., 2002). Besides, change processes need drivers to occur. Innes and Mitchell (1990) distinguished three types: facilitators, motivators and catalysts. Facilitators comprise a set of factors conducive to change: they are necessary but in themselves not sufficient for change to occur. Motivators are factors that influence change processes in general manner: they provide decision makers the reasons and grounds to initiate and permit change. Catalysts contain factors directly related to the timing of change: they are occurrences that lead directly to the initiation of change and provide the opportunity for change to take place (Groot and Lukka, 2000). 
Brown and Potoski (2003) showed that institutional forces exert significant influences on governments' service production choices. For example, the councilmanager status influences the service production decisions of governments. In a study on contracting out using data for 500 cities in Southern California, Joassart-Marcelli and Musso (2005) showed that service provision and production arrangements tend to be made at the time of city formation, and that political and institutional rigidity limit the extent to which arrangements subsequently are changed. This reflects the possibility of path-dependency. Brown et al. (2008) showed that service delivery choices exhibit strong inertia, and when change occurs the previous service delivery mode influences the likelihood of changing to other service-delivery modes in important ways. Wassenaar et al. (2010) described institutional motives that might play a role in considering contracting out as the stability of municipal service provision and the legal status of municipal employees. Despite the potential elucidation of this literature on the concept of contracting out, neo-institutional literature has not been tested extensively on this subject yet.

\section{Research questions}

Despite the vast amount of studies, a comprehensive explanation for municipal decisions between self-supply and contracting out is still not available. Besides, these studies lack in general an explanation for the cause of considerations about contracting out. Most studies are based on multivariate regression analyses, used to investigate the relationship between the actual level of contracting out to a range of municipal characteristics. These characteristics - as the number of inhabitants or the level of the local tax rate - are related to the factors that might influence the decision-making on contracting out (as for both examples the scale and the budgetary situation of the municipality). They give an indirect analysis of the motives in favour of or against contracting out, as they attempt to discover the revealed preferences behind this decision.

This study adds to this literature by directly interviewing the responsible municipal managers about the motives relevant to decision-making on contracting out. With these interviews, we explore: (1) the cause of contracting out discussions and decisions, (2) the most relevant motives for municipalities in decisions for contracting or not, and (3) motives for the choice of the mode of the provision of the service (i.e. whether it is publicly - in-house or out-house - or privately produced). This case study approach provides the opportunity to both investigate the standard theoretical concepts from public choice and transaction cost theory, as to explore the relevance of institutional and pragmatic motives.

However, we notice that psychological research has shown that a drawback of this interview approach is the fact that it is for people, in general, difficult to describe the 
motives for their decisions (Johansson, 2005). Therefore, this study is useful to understand contracting out behaviour, although general applicable conclusions are difficult to draw. Otherwise, for the decisions we investigate in this study, not personal but organisational motives are relevant, and we expect that these are more objectively defined.

\section{Method}

For this study, we held 17 semi-structured interviews with the municipal executives. This principal municipal civil servant is the main advisor of the municipal Board of Mayor and Aldermen, and is responsible for the management of the municipal organisation. Therefore, he (or she) plays a major role in discussions on contracting out or not. We made an interview protocol we tested with one municipal employee and two researchers with a broad experience in this kind of interviews. The municipalities were chosen using a stratified sample design. As previous research shows, the municipal size, the political constellation and the financial position of the municipality might be relevant aspects in understanding differences between municipalities (Dijkgraaf et al., 2003; Bel and Fageda, 2007). We used four categories of size (see table 2). For the political constellation of the municipality, we counted the relative number of aldermen with a membership of one of the left-wing parties (socialist party, green left and the labour party) in April 2009 (three years after the last municipal elections). In case this indicator comes at 50 percent, the relative number of left-wing members of the municipal council is decisive for the nomination left-wing vs. right-wing. As we suppose the level of local taxes to be negatively related to the financial prosperity, we use the net local tax burden for a fourperson household ( 2 adults, 2 children) in 2008, consisting of the real estate tax, the sewerage charge and the refuse collection charge (Allers et al., 2008), as the indicator. For each combination of these three municipal characteristics, we held at least one interview. As municipal mergers might be a relevant aspect for this issue, we held four of the interviews in municipalities that merged in recent years or will merge in the near future. ${ }^{3}$ We sent an e-mail or letter to the municipal executive to ask for participation in this study including an explanation of the research theme and the headlines of the interview. Most of the municipalities were directly willing to participate. In five municipalities, the executive delegated this interview to a deputy or another manager, in most cases due to their more long-term affiliation with the municipality.

\footnotetext{
${ }^{3}$ The interviews were held in Amersfoort, Breukelen, Groningen, Heerenveen, HoogezandSappemeer, IJsselstein, Krimpen aan den IJssel, Leeuwarden, Lelystad, Midden-Delfland, Nunspeet, Oostzaan, Purmerend, Rijnwoude, Westland, Zijpe, and Zwolle. Appendix A describes the main characteristics of these municipalities.
} 
The interviews were held in the months April until June 2009 and lasted between an hour and an hour and a half. ${ }^{4} \mathrm{~A}$ report was written directly afterwards, based on the notes made during the interview. This report was sent directly to the interviewees for comment and were approved all. Based on the interview reports, the answers were categorized. We coded the texts of the reports on all relevant aspects (cause, motives, and mode of service provision, all with the explanation). These data were used for analysing information presented in the interviews. Besides, we made a database of the quantitative answers.

To discuss the municipal motives for contracting out, the interviews consisted of four sections:

- A: An explorative open question on the main motives in considerations made on contracting out and the main catalysts for these discussions.

- B: Closed questions about the relevance on the motives as described in table 1 . This table shows for each motive an explanation and the relevant theoretical basis. For each motive, we asked the extent of relevance (on a five point Lickert-scale), whether it was a motive in favour or against contracting out, and an explanation for the answers.

- C: An explorative discussion on three recent or actual cases of considering or deciding about contracting out. We discussed the main motives for the actual or recent decision, the causes for the discussion and the mode of the service provision as decided with its arguments.

- D: Closed questions on, for ten specified activities, the causes and motives for the current mode of service provision: (1) cleaning services, (2) canteen services, (3) security, (4) payroll administration, (5) IT-services, (6) social services, (7) refuse collection, (8) small infrastructure works, (9) valuation of real estate, and (10) park management.

The questions in the sections A, B and C are used to explore the relevance of the several motives on contracting out as described in the literature and to find additional motives on this issue. The questions in sections B and D are more structured and these results are presented in tables. Besides, these results, in particular the relevance of the additional motives as provided in the interviews, are tested statistically to assess their relative importance. Appendix B contains the Interviewprotocol as used for this study.

\footnotetext{
${ }^{4}$ Two interviews with merging municipalities were held in February 2010.
} 
Table 1 Motives for contracting out or not

\begin{tabular}{|c|c|c|}
\hline Motive & Explanation & Literature \\
\hline \multicolumn{3}{|l|}{ Public choice motives } \\
\hline Efficiency & The lower costs of external service provision & $\begin{array}{l}\text { Bel et al., 2007; Bel and } \\
\text { Fageda, } 2007\end{array}$ \\
\hline $\begin{array}{l}\text { Quality of external } \\
\text { service provision }\end{array}$ & The higher quality of external service provision & $\begin{array}{l}\text { Brudney et al., 2004; Hodge, } \\
\text { 2000; Warner and Hebdon, } \\
2001\end{array}$ \\
\hline Political patronage & $\begin{array}{l}\text { The influence of local interested parties, as lobby } \\
\text { groups, labour organisations or local businesses }\end{array}$ & $\begin{array}{l}\text { Bel et al., 2007; Bel and } \\
\text { Fageda, } 2007\end{array}$ \\
\hline Public private ideology & $\begin{array}{l}\text { Opinion of the role of the government in } \\
\text { comparison with the market }\end{array}$ & $\begin{array}{l}\text { Bel et al., 2007; Bel and } \\
\text { Fageda, } 2007\end{array}$ \\
\hline \multicolumn{3}{|l|}{ Transaction costs motives } \\
\hline Transaction costs & $\begin{array}{l}\text { Transaction costs that come with the process of } \\
\text { contracting, as costs of planning, adapting, and } \\
\text { monitoring. }\end{array}$ & Brown and Potoski, 2005 \\
\hline Costs of assets & $\begin{array}{l}\text { The relatively high costs of investments that have to } \\
\text { be made for service provision. }\end{array}$ & Brown and Potoski, 2005 \\
\hline \multicolumn{3}{|l|}{ Institutional motives } \\
\hline $\begin{array}{l}\text { Independence of external } \\
\text { providers }\end{array}$ & $\begin{array}{l}\text { The independence of external providers from the } \\
\text { municipal organisation }\end{array}$ & -1 \\
\hline Local employment & $\begin{array}{l}\text { Concern for employment in the municipality itself, } \\
\text { especially for organisations for sheltered } \\
\text { employment }\end{array}$ & Wassenaar et al.., 2010 \\
\hline Core tasks & $\begin{array}{l}\text { Core tasks as defined by the municipality itself } \\
\text { (tasks that cannot be contracted out, due to the } \\
\text { municipal responsibility). }\end{array}$ & -1 \\
\hline $\begin{array}{l}\text { Stability of service } \\
\text { provision }\end{array}$ & The stability of service provision & Wassenaar et al.., 2010 \\
\hline $\begin{array}{l}\text { Availability of } \\
\text { alternatives }\end{array}$ & $\begin{array}{l}\text { The availability of more than one external service } \\
\text { provider. }\end{array}$ & Dijkgraaf and Gradus, 2007 \\
\hline $\begin{array}{l}\text { Introduction of the VAT- } \\
\text { compensation fund }\end{array}$ & $\begin{array}{l}\text { The opportunities as arisen with the introduction } \\
\text { with the VAT-compensation fund in } 2003 .\end{array}$ & Wassenaar et al.., 2010 \\
\hline \multicolumn{3}{|l|}{ Pragmatic motives } \\
\hline $\begin{array}{l}\text { Availability of expertise } \\
\text { in the own organisation }\end{array}$ & $\begin{array}{l}\text { The availability of expertise and quality in the own } \\
\text { organisation as needed for an adequate service } \\
\text { level. }\end{array}$ & Wassenaar et al., 2010 \\
\hline Flexibility & $\begin{array}{l}\text { The flexible design of the municipal organisation, } \\
\text { because of the lack of a constant level of work. }\end{array}$ & Bel and Fageda, 2010 \\
\hline $\begin{array}{l}\text { Available quantity of } \\
\text { personnel }\end{array}$ & $\begin{array}{l}\text { The availability of enough personnel for an } \\
\text { adequate service level. }\end{array}$ & Wassenaar et al., 2010 \\
\hline
\end{tabular}

1. As far as we know, these motives are not described in previous studies, but are hypothesized in this explorative research study 
The motives as presented in table 1 are the principle hypotheses of public choice and transaction costs theory. As institutional literature has not been tested extensively on the issue of contracting out, we suppose some motives, partly based on Wassenaar et al. (2010) to play a role. Common aspect of these institutional motives is that they are related to the potential pressure exerted by both external (citizens) and internal (employees) constituencies on the organization to conform to a set of expectations. We suppose the following institutional motives to be relevant from this point of view: 'independence of external providers, 'local employment', ‘core tasks', ‘stability of service provision', 'availability of alternatives' and 'the introduction of the VAT-compensation fund'. Finally, as previous research (Bel and Fageda, 2007; Wassenaar et al., 2010) has shown, local governments may use pragmatic motives as well. Therefore, we include some more organizational and pragmatic motives. ${ }^{6}$ Some of these motives are not described in previous studies, but are hypothesized in this explorative research. We notice that some of these motives might be related to each other and describe partially the same aspect. In the interviews, we used explanations of each of the motives as described in the protocol in appendix B to focus on the actual motive. Based on transaction cost and institutional theory, we expect differences in the extent of contracting out between types of activities. In section 5.3 we describe the results for activities with high or low levels asset specificity and service measurability and internal vs. external activities.

\section{Results}

The interviews lead to a broad range of observations on contracting out behaviour of municipalities. Section 5.1 describes the catalysts of discussions on contracting out or not as provided in sections A, C and D of the interviews. Conclusions on the motives for contracting out as discussed in all four sections of the interviews are presented in section 5.2. Section 5.3 elaborates on the motives for the actual or future mode of service provision as based on sections $\mathrm{C}$ and $\mathrm{D}$ of the interviews. We describe both the relevance of the motives as described in the literature so far and the additional motives as provided in the interviews. Section 5.4 provides a number of statistical analyses on the data provided in section $\mathrm{D}$ of the interviews, to structure some mere qualitative results of the preceding sections. Besides, these can be used to assess the relative importance of the various motives.

\footnotetext{
${ }^{5}$ The public choice motive of 'political patronage' might be related to institutional theory as well. The public choice motive of 'quality of external service provision' might be related to the institutional motive 'stability of service provision' as well.

${ }^{6}$ In the interviews, we discussed the motives 'optimal scale of the municipal organization', 'risk avoidance', and 'experiences in other municipalities' as well. However, these motives did in general not lead to relevant outcomes.
} 


\subsection{Catalysts}

Based on sections A, C and D of the interviews, we analysed the catalysts for discussions about contracting out. In most municipalities, the mode of service provision is not a relevant managerial or political issue. Municipalities do not regularly evaluate their organisational performance and the costs and quality of service provision. In fact, if the activity has an adequate performance level and complaints from own employees, municipal politicians or inhabitants do not occur, a catalyst for a discussion on the contracting out of this activity is, in general, lacking. For the ten investigated standard activities, most municipalities have not ever discussed contracting out IT-services, the payroll administration, canteen services, and social services. Some municipal managers explain that the profitable financial position of the municipality or other managerial issues as the merger of municipalities impeded these discussions.

In case of structural dissatisfaction and complaints about the performance, the execution of tasks and the mode of the service provision becomes a relevant managerial topic. Dependent of the extent of the complaints, this can become a politically relevant issue as well, especially for external tasks with a citizen focus such as social services or the valuation of real estate. Structural underperformance can appear in different forms, as the quality of service provision, the lack of adequate expertise or high levels of absence through illness. Some municipalities report the poor quality of service provision of external providers as a reason to start the discussion about the self-supply of the services. For example, in two municipalities the lack of quality of the private valuation of real estate caused extra legal work for the municipality. By contracting in, this task was executed more appropriately.

Some municipalities report - as an example of path-dependency - the building of new accommodations (e.g. town hall, swimming pool) as relevant moments for considering the mode of the service provision, especially for canteen and cleaning services in these buildings. Another relevant moment for starting the discussion about the mode of the service provision is a change of the service in itself, due to new legislation or the decentralization of tasks. Remarkably, as far as the interviews show, the merger of municipalities was in the interviewed municipalities not a catalyst for considering the mode of service provision.

Only one of the seventeen municipalities reports a regular evaluation of the mode of service provision of all activities, by systematically comparing own performance with external service providers. A small number of municipalities had discussions years ago about their core tasks. In the nineties, this type of organizational evaluation was held in many municipalities (Hendriks and Tops, 2003). Main goal was to decide which tasks should remain part of municipal services and which tasks should be contracted out or privatised. Due to the spirit of these times, most discussion started from the premise that 
private parties would outperform municipalities in the execution of tasks. However, most of the interviewees conclude that these evaluations lacked consequences, except in case of major financial problems that forced severe expenditure cuts. Some municipalities report ideologically driven discussions about the execution of municipal tasks, mostly started by relatively powerful aldermen that were politically responsible for the municipal organization. However, these aldermen were both of left-wing (labour party) as rightwing (liberals, conservatives) parties.

As an example of pragmatism, some municipalities describe a change of service provision gradually in case one or more employees retire or move to another job. Municipal managers explain that - due to the legal status of their employees - contracting out can come with high costs of buying off their relatively profitable conditions of employment as especially the un- and low-skilled job workers receive, compared to the private sector, a relatively high wage-level. In practice, some municipalities make arrangements with private contractors to take over of employees, although in many cases this is complicated.

The potential efficiency gains or higher service quality are, on their own, not relevant motives to consider the contracting out of municipal services. In most cases, other change drivers are necessary to catalyse this consideration. Although the introduction of the VAT-compensation fund could have been such an external catalyst, none of the interviewed municipal managers states that this caused a change of service provision.

\subsection{Motives}

Table 2 shows the relevance of all motives, as based on section A and B of the interviews. The first column shows the relative number spontaneous answers of the motives of section A. The other columns show the results of section $\mathrm{B}$, the assessment of the motives on a 5-point Lickert-scale. In bold, the table shows the scores more positive than neutral (score lower than 3). In most cases, the answer is positively formulated (the motive is in favour of contracting out), although for a small number of motives (public private ideology, efficiency) the motive might lead to the conclusion of self-supply. We tested with a Mann-Whitney test the differences in scores for the different pairs of municipalities (municipalities with less than 40.000 inhabitants vs. municipalities with more than 40.000 inhabitants; left-wing vs. right wing municipalities; municipalities with high taxes vs. municipalities with low taxes). ${ }^{7}$ As shown in this table, only for a small number of pairs, we find significant differences in scores. Smaller municipalities find the motives 'stability of service provision', 'availability of expertise in the own organisation'

\footnotetext{
${ }^{7}$ A Kolmogorov-Smirnov test on the differences between the four groups of size did not give significant differences.
} 
and 'available quantity of personnel' significantly more relevant than larger municipalities. For some motives, low and high-tax municipalities have significant different scores, however, these scores show that the motives are still not relevant, as they are higher than ' 3 '.

\section{Public choice motives}

The efficiency-motive is with a score of 1.8 (table 2) by far the most important motive in considerations about contracting out. For many activities, private or public companies can provide services at a lower cost than municipalities, due to scale advantages, more specialization and more standardization. The efficiency motive is not always based on a clear cost comparison, but often on the conviction of lower costs of external parties. Some municipalities describe experiences with increasing costs once the task is contracted out. For refuse collection such behaviour is well known in literature (e.g. Szymanski, 1996). The efficiency motive is most relevant for internal activities (canteen services, cleaning services, security, payroll administration, IT-services) or park management, refuse collection, small infrastructure works or management of accommodations than for mere public tasks with an external scope as social services and culture management. As table 2 shows, municipalities with lower tax rates or left-wing oriented municipalities seem to find the efficiency motive more relevant than municipalities with higher tax rates or right-wing municipalities.

The quality of external service provision is with a score of 3.0 less relevant, although especially the smallest municipalities use this motive. A higher quality level of external service providers is attributed to specialisation and economies of scale. For some municipalities, the disappointing quality level is the motive for contracting in these activities. Especially for the valuation of real estate, municipalities describe the lack of quality of private providers and the legal consequences of their underperformance. Some municipal managers explain that their own personnel work at a higher quality level due to the commitment to their work for the municipality. This quality motive is most relevant for internal activities (cleaning services, canteen services, payrolladministration), although some municipalities used this motive for park management and valuation of real estate as well. 
Table 2 Results of section A and B, values lower than ' 3 ' in bold ${ }^{1}$

\begin{tabular}{|c|c|c|c|c|c|c|c|c|c|c|c|c|}
\hline & \multirow{2}{*}{$\begin{array}{l}\text { Relevance } \\
\text { in } \\
\text { general }^{2}\end{array}$} & \multirow[b]{2}{*}{ average } & \multicolumn{6}{|c|}{ number of inhabitants } & \multirow[b]{2}{*}{\begin{tabular}{|l} 
right \\
wing
\end{tabular}} & \multirow[b]{2}{*}{$\begin{array}{l}\text { left } \\
\text { wing }\end{array}$} & \multirow[b]{2}{*}{$\begin{array}{l}\text { high } \\
\text { taxes }\end{array}$} & \multirow[b]{2}{*}{$\begin{array}{l}\text { low } \\
\text { taxes }\end{array}$} \\
\hline & & & $20.000-$ & $\begin{array}{l}20.000 \\
- \\
40.000 \\
\end{array}$ & $\begin{array}{l}40.000 \\
- \\
100.000 \\
\end{array}$ & $100.000+$ & 40.000- & $40.000+$ & & & & \\
\hline \multicolumn{13}{|l|}{ Public choice theory motives } \\
\hline Efficiency & $31 \%$ & 1,8 & 1,6 & 1,8 & 1,5 & 2,3 & 1,7 & 1,9 & 1,9 & 1,6 & 2,0 & 1,5 \\
\hline Quality of external service provision & $8 \%$ & 3,0 & 2,1 & 3,0 & 4,0 & 3,1 & 2,5 & 3,6 & 3,0 & 3,0 & 3,3 & 2,7 \\
\hline Political patronage & $2 \%$ & 4,3 & 5,0 & 3,5 & 4,5 & 4,1 & 4,3 & 4,3 & 4,2 & 4,5 & 4,2 & 4,4 \\
\hline Public private Ideology & $12 \%$ & 2,9 & 4,2 & 1,5 & 2,8 & 2,8 & 3,0 & 2,8 & 3,0 & 2,8 & 3,4 & 2,3 \\
\hline \multicolumn{13}{|l|}{ Transaction costs theory motives } \\
\hline Transaction costs & $1 \%$ & 4,0 & 3,8 & 3,8 & 4,5 & 3,9 & 3,8 & 4,2 & 3,6 & 4,4 & 3,8 & 4,1 \\
\hline Costs of investments & $0 \%$ & 4,1 & 4,2 & 3,5 & 4,0 & 4,8 & 3,9 & 4,4 & 4,0 & 4,3 & $4,6^{*}$ & $3,6 *$ \\
\hline \multicolumn{13}{|l|}{ Institutional motives } \\
\hline Independence of external providers & $0 \%$ & 4,1 & 4,6 & 3,3 & 4,5 & 4,0 & 4,0 & 4,3 & 4,2 & 4,0 & $4,6 * *$ & $3,6 * *$ \\
\hline Local employment & $1 \%$ & 3,9 & 4,2 & 3,0 & 4,5 & 4,0 & 3,7 & 4,3 & 4,1 & 3,8 & 4,3 & 3,8 \\
\hline Core tasks & $2 \%$ & 4,1 & 4,6 & 3,5 & 3,1 & 5,0 & 4,1 & 4,1 & 4,0 & 4,2 & 4,1 & 4,1 \\
\hline Stability of service provision & $9 \%$ & 3,2 & 2,2 & 2,3 & 4,3 & 4,3 & $2,2 *$ & $4,3^{*}$ & 2,9 & 3,5 & 3,3 & 3,0 \\
\hline Availability of alternatives & $2 \%$ & 3,3 & 2,8 & 3,0 & 3,8 & 3,8 & 2,9 & 3,8 & 3,0 & 3,6 & 3,8 & 2,8 \\
\hline Introduction of the VAT-compensation fund & $0 \%$ & 4,5 & 4,4 & 4,5 & 4,3 & 4,8 & 4,4 & 4,5 & 4,6 & 4,4 & $4,8^{*}$ & $4,1^{*}$ \\
\hline \multicolumn{13}{|l|}{ Pragmatic motives } \\
\hline Availability of expertise in the own organisation & $9 \%$ & 2,8 & 2,2 & 2,3 & 3,0 & 3,8 & $2,2 * *$ & $3,4^{* *}$ & 2,3 & 3,3 & 2,7 & 2,9 \\
\hline Flexibility & $2 \%$ & 3,3 & 3,4 & 2,8 & 3,0 & 4,1 & 3,1 & 3,6 & 3,3 & 3,4 & 3,4 & 3,2 \\
\hline Available quantity of personnel & $0 \%$ & 3,6 & 3,5 & 2,3 & 3,8 & 4,9 & $2,9 * *$ & $4,3^{* *}$ & 3,3 & 3,9 & 3,7 & 3,4 \\
\hline
\end{tabular}

1. The scores had the following meaning: 1: very important, 2: important; 3 neutral, 4 not important, 5: very unimportant

2. The figure shows the relative value of each of the answers on section A of the interview. As municipalities provided other motives as well, the percentages do not add up to $100 \%$ (especially keeping influence on task execution; 6\% and involvement of own personnel, 2\%).

* / ** Differences are significant at $\mathrm{p}<0.10$ / 0.05 (Mann Whitney U-test). 
The political patronage motive - by for example labour organisations - is by municipal managers with a score of 4.3 not assessed as a relevant motive for contracting out or not. Works councils may play a role in the considerations about contracting out, and delay at most the process, but do not determine the outcome. Local businesses and their organizations are not relevant in the discussion about contracting out. However, we cannot exclude that these outcomes are social preferable answers on the patronage issue.

The public private ideology-motive is relevant, especially for municipalities with lower tax rates. The score between left and right-wing municipalities are almost alike, although the interviews show that a great number of more right-wing municipalities have a strong opinion of the division of roles between the public and private sector (they contract out, unless the market is not able to supply the service at an adequate level). In most municipalities, this ideological approach is historically based, by opinions of alderman or municipal managers with a strong informal position.

\section{Transaction costs motives}

The transaction costs of contracting out are not considered a relevant aspect. Some municipalities describe the complexity of the European procurement rules as a barrier. Some municipalities mention disappointing levels of increasing costs for directing the external suppliers once the activity is contracted out.

The costs of investments for the supply of activities are not a relevant motive for considering contracting out. As municipalities are by law obliged to use an accrual accounting system, the cost of assets are divided on the years which the investment is used. So, the incidental costs of investment might not matter. However, incidentally, the aldermen have to ask the city council for permission for contracting a high loan. In these cases, the costs of investments might be a relevant motive. High investments may cause a discussion on contracting out due to the potentially sub optimal use of the assets.

\section{Institutional motives}

The independence of external providers is hardly a relevant motive (score of 4.1). For some municipalities, this motive is used for contracting out the valuation of real estate to limit the discussion with owners of real estate about the estimated value.

The motive of concern for local employment is in general not relevant. Nevertheless, some municipalities try to make use of the sheltered employment due to their budgetary and political responsibility for their employees, for example for park management. Some municipalities included in their tendering procedures that at least one or two local private companies must be offered an opportunity to tender.

Some of the municipalities started about a decade ago discussion about which task they should execute and which tasks should be left to other organisations or the 
market. Most interviewees concluded that these 'core task discussion' did not have effect on the mode of service provision, although in combination with other relevant factors as a deteriorating financial position, these discussions might have had any consequence.

The stability of service provision is a relevant motive, especially for smaller municipalities (table 2). As they explain, their size is too small for a constant level of service provision for a number of activities. As one of these smaller municipalities described, for example with one garbage truck, garbage will not be collected in case of inspection or repair of the truck. Comparable effects occur in case of absence through illness or mobility to other work of employees. Especially for canteen services, small infrastructure works and cleaning services, this motive is relevant. Some motives - as the quality of external service provision, the expertise of the own municipal organisation, the available quantity of personnel and the stability of service provision - are mutually related, as they all describe an aspect of the problems for smaller municipalities to execute their services at an adequate level. As table 3 shows, the percentage of contracting out - both public as private - is relatively high for the smaller municipalities.

Especially for smaller municipalities, the availability of alternatives is a relevant motive in considering contracting out (score of 2.9). They explain that only in a nonmonopolistic market for contracting out, for having a real alternative in case of disappointing service supply, especially for IT-services, refuse collection and the payrolladministration.

The introduction of the VAT-compensation fund did not play an explicit role in discussions about contracting out. None of the municipalities started at the time of introduction a discussion about the opportunities. However, as the efficiency motive is quite relevant, most of the municipalities agree that at least implicitly, the fund might have had a relevant impact as cost comparisons between self-service and contracting out changed.

\section{Pragmatic motives}

The availability of expertise in the own organisation is a relevant motive for especially smaller municipalities (<40.000). For some expertise and tasks (e.g. urban development management, policy preparation and legal services, social services, valuation of real estate, building and environmental supervision, complex projects) smaller municipalities have not the scale to organize these activities themselves at an adequate level.

For some activities, municipalities need a flexible work force (e.g. valuation of real estate and park management) due to the variable amount of work. As the legal duty to valuate all real estate changed in 2007 from once a four-year period to once a year, this activity has received a more constant level of work and the flexibility motive has less relevance and some municipalities contracted in this task. Interviewees report that the 
municipal collective labour agreement is relatively expensive with respect to overtime work (especially evenings, weekends and holidays). Therefore, for these days hiring of external personnel is economically attractive.

Especially for smaller municipalities, for some activities it is rather difficult to have adequate personnel in office. The motive of the available quantity of personnel has therefore a relationship with the motives as the availability of expertise, for example traffic expertise, valuation of real estate and expertise for urban development.

The interviewees provided some motives, in addition to the list in table 1 . Some explain that by contracting out, it is easier to determine a desired level of service quality due to the more formal relationship with external service providers. However, other municipalities use internal service level agreements intending the same, referring to the importance of informal relationships by managing activities. In some municipalities, contracting out is explicitly used to diminish the political discussions about the service level of execution of municipal tasks, for example the programme of cultural organizations as some more pronounced conservative and right-wing council members might have difficulties with certain forms of art as facilitated by public organizations. Some municipalities describe the fear, particularly by politicians, of a loss of influence on the task execution as relevant motive against contracting out. This motive seems be more relevant for tasks with an external scope, than for internal activities. For these internal activities and park management, the desire to diminish the extent of managerial executive responsibility is a relevant motive. Especially because of the working hours in the evenings, the nights, and the weekends (cleaning services, security), direct management is relatively complex and expensive. Incidentally, liability on the level of service provision and customer orientation are mentioned as a motive in favour or against contracting out. However, for none of these additional motives, the different groups of municipalities scored values lower than ' 3 ' / neutral, on the 5-point Lickert-scale as described at table 2.

For a number of situations, the interviewees were not able to label the motive for the actual mode of service provision, in most cases due to the fact that the actual state was stable since many years. Especially for cleaning services, park management, small infrastructure works and security, this answer was given. This might be an indication that especially for these types of activities, discussions about contracting out were held many years ago.

\subsection{Mode of the service provision}

In this study, we distinguish three types for the mode of service provision: self-supply, public contracting out and private contracting out. Public contracting out may have various forms as the supply by another neighbouring municipality or an intermunicipal 
corporation under the responsibility and ownership of a group of municipalities Based on part $\mathrm{C}$ and $\mathrm{D}$ of the interviews, we have a number of observations and conclusions.

For a great number of municipalities, contracting out of some their activities has not been discussed, and as a result, the municipality still provides the service itself, in particular for IT-services, the payroll-administration, canteen services and the social services. The quality of external service provision is a motive for self supply for park management and valuation of real estate. Social services are considered to be a core task, and to be supplied by the municipality itself. In some cases, self-supply is argued by pointing at the need for getting to grips on the execution of activities. Only in a small number of cases, the comparison between self-supply and contracting out leads to the conclusion that self supply is preferable (especially refuse collection, IT-services, assessment of real estate and park management). For the valuation of real estate, some municipalities decided for contracting in, due to the poor service quality of external providers.

The most important motive for contracting out to public organisations is that the municipality is convinced that self-supply is no longer optimal, but that due to the nature of the task and the legal municipal responsibility, contracting out to another public organisation as, for example, another municipality is the only alternative (e.g. social services, environmental inspection and public education). Another important motive for public contracting out is the opportunity to profit from scale advantages, but still providing opportunity to getting to grips on the execution of municipal tasks, via shareholding of the public company or contracting out to a known public party (for example a local housing corporation). However, organizations for inter-municipal cooperation are in many cases not a real alternative due to the conflicting interests of the participating municipalities. Some municipalities explain that they have more influence in case of outsourcing to a private company as it provides the opportunity to make more clear agreements with only one other external party.

In some cases, municipalities use their sheltered employment organisation for internal tasks as cleaning services and park management. In addition, municipalities prefer to join a well-known party and therefore the availability of a public alternative is a motive.

Private contracting out is especially used for internal activities as cleaning services, canteen services and security. The decision to contract out privately is most based on a comparison of the costs, the quality and the stability of service provision under different regimes, especially in case of a market for this type of activity with more alternatives. However, in a large number of cases, we find that a fair comparison was not made, but that the conviction of a better private alternative led to contracting out. 
In some cases, municipalities describe a combination of the modes of service provision. For example, for park management and the valuation of real estate, the municipality itself supplies a basic level of services, and in times of relative large amounts of work, private contractors supply extra capacity.

\subsection{Motives on contracting out, for specific municipal activities}

Based on section $\mathrm{D}$ of the interviews, we made a database of 170 activities, describing the mode of service provision on each of the ten standard activities, in each of the seventeen municipalities. For each situation, the interviews provided one or more motives for the actual state of service delivery. These data give - in addition to the qualitative description of the previous subsections - the opportunity to test a number of results of this study statistically. First, we investigate the differences in contracting out choices between types of municipalities (table 3). Secondly, we test the differences in contracting out choices for various types of activities (table 4). Finally, we test the relationship between the type of service provision and the motives as described in this study (table 5).

Table 3 shows for each of the subgroups of municipalities (according to size, political constellation and financial situation) the percentages of activities by the three types of service provision (self supply, public contracting out and private contracting out), as based on this section of the interviews. For all 17 municipalities, we calculated a percentage of the ten standard activities in each of the three categories of service provision.

We tested the differences in these percentages with a Mann-Whitney U-test, for each of the pair of types of municipalities. As table 3 shows, the percentage of public contracting out is - on a $10 \%$ level - significantly higher for the municipalities with less than 40.000 inhabitants than for the larger municipalities. For smaller municipalities, it is attractive to share the execution of tasks, or to outsource these to another municipality. Right-wing municipalities have - as according to the literature might be expected significantly higher percentages of contracting out to the private sector than left-wing municipalities. The other differences are not significant. 
Table 3 Contracting out, different types of service provision, in \% of all municipalities

\begin{tabular}{|l|c|c|c|}
\hline & Self supply & Publicly contracted & Privately contracted \\
\hline $40.000-$ & $32 \%$ & $16 \%^{*}$ & $52 \%$ \\
\hline $40.000+$ & $44 \%$ & $7 \%^{*}$ & $50 \%$ \\
\hline & & & $54 \%^{* *}$ \\
\hline right-wing & $36 \%$ & $10 \%$ & $48 \% * *$ \\
\hline left-wing & $39 \%$ & $14 \%$ & $49 \%$ \\
\hline & & & $54 \%$ \\
\hline high local taxes & $40 \%$ & $11 \%$ & $51 \%$ \\
\hline low local taxes & $34 \%$ & $13 \%$ & ( \\
\hline
\end{tabular}

*/** Differences are significant at $\mathrm{p}<0.10$ / 0.05 (Mann Whitney U-test).

Table 4 presents - based on the same dataset of 170 activities - for different types of activities the actual mode of service provision. Based on transaction cost theory we distinguish the attributes asset specificity (whether specialized investments are required to deliver the service) and service measurability (how difficult it is for the contracting organization to measure the outcomes of the service or to monitor the activities required to deliver the service). For each of the ten standard activities, we scored both attributes based on an approach by Brown and Potoski (2003). ${ }^{8}$ Besides, we expect - based on institutional theory - differences in contracting out behaviour between activities having an internal focus (to the municipal organisation or employees) and activities with an external focus (to municipal citizens), as the last type may encounter more institutional pressure in case of underperformance. For all of the ten activities, we calculated percentages of the task execution in each of the three categories of service provision.

\footnotetext{
${ }^{8}$ Brown and Potoski (2003a) asked 75 municipal managers about the level of asset specificity (whether specialized investments are required to deliver the service) and the service measurability (how difficult it is for the contracting organization to measure the outcomes of the service or to monitor the activities required to deliver the service) of 64 municipal activities. Although the scores are given in a different context, for the use of this study, we expect them to be appropriate like in Hefetz and Warner (2007) and Brown et al. (2008). Due to the fact that the 64 activities do not correspond fully with the ten activities in our study, we have chosen the activities corresponding the most. Hereafter we describe the ten standard activities, with between brackets the activity we use as a proxy: cleaning services (street / parking lot cleaning); canteen services (secretarial services); security (building security); payroll administration (payroll); IT-services (data processing); social services (public health programs); refuse collection (commercial solid waste collection); small infrastructure works (street repair); valuation of real estate (tax assessing); park management (parks and landscape maintenance / tree trimming / planting on rights of way).
} 
Table 4 The mode of service provision, according to the characteristics of the activity

\begin{tabular}{|l|l|l|l|}
\hline & $\begin{array}{l}\text { Self } \\
\text { supply }\end{array}$ & $\begin{array}{l}\text { Publicly } \\
\text { contracted }\end{array}$ & $\begin{array}{l}\text { Privately } \\
\text { contracted }\end{array}$ \\
\hline $\begin{array}{l}\text { low asset specificity (payroll-administration, canteen } \\
\text { services, security, cleaning services, park management) }\end{array}$ & $31 \%$ & $6 \% *$ & $64 \%$ \\
\hline $\begin{array}{l}\text { high asset specificity (refuse collection, social services, } \\
\text { IT-services, infrastructure works, valuation of real } \\
\text { estate) }\end{array}$ & $44 \%$ & $18 \% *$ & $39 \%$ \\
\hline $\begin{array}{l}\text { high service measurability (refuse collection, payroll- } \\
\text { administration, security, infrastructure works, cleaning } \\
\text { services, park management) }\end{array}$ & $25 \% * *$ & $11 \%$ & $65 \%$ \\
\hline $\begin{array}{l}\text { low service measurability (social services, canteen } \\
\text { services, IT-services, valuation of real estate) }\end{array}$ & $56 \% * *$ & $13 \%$ & $31 \%$ \\
\hline $\begin{array}{l}\text { internal activities (payroll-administration, canteen } \\
\text { services, security, IT-services, cleaning services) }\end{array}$ & $39 \%$ & $7 \%$ & $54 \%$ \\
\hline $\begin{array}{l}\text { external activities (refuse collection, social services, } \\
\text { infrastructure works, valuation of real estate, park } \\
\text { management) }\end{array}$ & $35 \%$ & $16 \%$ & $48 \%$ \\
\hline \begin{tabular}{l} 
total \\
\hline
\end{tabular} & $37 \%$ & $12 \%$ & $51 \%$ \\
\hline ( $1 \% *$ Differes & & \\
\hline
\end{tabular}

* / ** Differences are significant at $\mathrm{p}<0.10$ / 0.05 (Mann Whitney U-test).

We tested the differences in these percentages with a Mann-Whitney U-test, for each of the pair of types of activities (low vs. high asset specificity, high vs. low service measurability and internal vs. external activities). Activities with higher asset specificity have a higher chance of being contracted out to a public provider than activities with lower asset specificity. For smaller municipalities, it might be attractive to share their assets with other municipalities in intermunicipal corporations. Also concomitantly with transaction costs literature, we see that activities with a low service measurability, have a higher chance of being executed in-house by the municipality itself. The differences in contracting out decisions between internal and external activities are statistically not significant.

\section{Multivariate analyses of motives for service provision}

Finally, we test in the following model whether the actual mode of service provision can be explained by the motives as described in this study. In addition to the more qualitative description of the motives in section 5.2, this analysis provides the opportunity to test the relative importance and the mutual relationships of the motives. For each of the ten standard-activities, we received in the interview on or more motives for the actual mode 
of service provision. Based on these data, we test the following simple standard binary logit model:

$$
Y_{i j}=f\left(\text { motive }_{i j k} ; \text { inh }_{j} ; \text { pol }_{j} ; \text { tax }_{j} ; \text { municipality }\right)_{j}
$$

$Y_{i j}$ is a dummy variable describing the actual mode of service provision of activity $i$ in municipality j. We tested two models. In model A, the dependent variable has value ' 1 ' in case of contracting out to a public of a private external service provider. In model $\mathrm{B}$, the dependent variable has value ' 1 ' in case of private contracting out. In all other cases, the value is ' 0 '. As the number of cases of contracting out to a public organisation is relatively small ( $\mathrm{n}=20)$, it is not possible to test this variable independently. ${ }^{9}$

For these analyses, we exploit the following variables:

- Motive $\mathrm{e}_{\mathrm{ijk}}$ : This variable had a value of ' 1 ' in case this motive is used in case of activity ' $\mathrm{i}$ ' in municipality ' $\mathrm{j}$ '. In most situations, interviewees gave one principal motive for a specific situation ( $\mathrm{k}=1)$, although in a number of cases more motives were reported ( $k=1: 2$ or $k=1: 3$ ). Due to the number of potential motives and the number of interviews and activities, it is not possible to test the relevance of each motive separately. Therefore, we apply the groups of motives as described and categorized in table 1: 'efficiency', 'quality of external service provision', 'public private ideology', 'institutional motives' and 'pragmatic motives'. ${ }^{10}$ The two additional motives as mentioned spontaneously in this part of the interviews, 'influence on task execution' and 'management of the execution', are added to the categories 'institutional motives' and 'pragmatic motives' respectively. This variable is a dummy, with a value ' 1 ' in case this motive is used. We notice that for a number of situations, the interviewees used more motives and these are included all.

- $\quad \operatorname{inh}_{\mathrm{i}}$ : as in table 3 , we include a ordinal variable representing the number of inhabitants, with ' 1 ' for the municipalities with less than 20.000 inhabitants, ' 2 'for municipalities with 20.000 - 40.000 inhabitants, ' 3 ' for municipalities with 40.000 - 100.000 inhabitants, and ' 4 ' for municipalities with more than 100.000 inhabitants.

\footnotetext{
${ }^{9}$ Besides, in such a model, it would not be relevant to test the choice for public contracting out vs. self supply or private contracting out. More relevant would be to test the decision for contracting out to a public organisation, given the fact that the activity was contracted out (to a public or private party).

${ }^{10}$ The motives 'political patronage' and 'transaction costs' are not given by the interviewees.
} 
- $\quad \operatorname{pol}_{i}$ as in table 3, we include a dummy variable representing the political constellation of the municipality, with ' 1 ' for the left-wing municipalities, and ' 0 ' for the right-wing municipalities. ${ }^{11}$

- $\quad \operatorname{tax}_{\mathrm{i}}$; as in table 3, we include a dummy variable representing the local tax level, with ' 1 ' for the municipalities with a relatively high tax rate, and ' 0 ' for the municipalities with a relatively low tax rate.

- municipality : We add seventeen dummy variables with value ' 1 ' for each of the municipalities.

Table 4 provides for both models the results. For matter of readability, we do not include the results of the municipality dummy variables. ${ }^{12}$

\footnotetext{
${ }^{11}$ Although this variable might theoretically be related to the ideology motive, they are different as the last one is used both in favour and against contracting out. Some interviewees use this motive as a pro-market attitude in the organisation, also in more left-wing municipalities.

${ }^{12}$ Appendix C provides the results, with the results of the municipal dummy variables as well.
} 
Table 4 Mode of service provision and motives

\begin{tabular}{|c|c|c|}
\hline & $\begin{array}{l}\text { Model A: Public or private } \\
\text { contracting out }=1 \text {, self } \\
\text { supply }=0\end{array}$ & $\begin{array}{l}\text { Model B: Private } \\
\text { contracting out }=1 \text {, self } \\
\text { supply or public } \\
\text { contracting out }=0\end{array}$ \\
\hline \multicolumn{3}{|l|}{ Motives } \\
\hline Efficiency & $2.183(0.535) * * *$ & $1.539(0.428) * * *$ \\
\hline Quality of external service provision & $1.017(0.638)$ & $0.781(0.520)$ \\
\hline Public private ideology & $-1.548(0.938) *$ & $-2.511(0.936) * * *$ \\
\hline Institutional motives $^{1}$ & $0.583(0.399)$ & $-0.149(0.369)$ \\
\hline Pragmatic motives $^{2}$ & $1.384(0.449) * * *$ & $0.905(0.349) * * *$ \\
\hline \multicolumn{3}{|l|}{ Control variables $^{3}$} \\
\hline Number of inhabitants ${ }^{4}$ & $-0.593(0.470)$ & $-0.294(0.361)$ \\
\hline $\begin{array}{l}\text { Political constellation, left-wing = } \\
\text { ' } 1 \text { ' }\end{array}$ & $-3.427(1.839) *$ & $-0.753(1.473)$ \\
\hline $\begin{array}{l}\text { Level of local tax rate, high taxes = } \\
\text { ' } 1 \text { ' }\end{array}$ & $-1.297(1.147)$ & $-0.098(1.056)$ \\
\hline Constant & $1.993(2.077)$ & $-0.119(1.663)$ \\
\hline -2 Log likelihood & 163.391 & 190.870 \\
\hline Cox \& Snell R ${ }^{2}$ & 0.301 & 0.231 \\
\hline Nagelkerke $\mathrm{R}^{2}$ & 0.410 & 0.308 \\
\hline
\end{tabular}

1. The motives 'local employment', 'core tasks', and 'influence on task execution', 'independence of external service providers’, ‘stability’, ‘availability of alternatives’.

2. The motives 'availability of expertise in the own organization', 'flexibility', 'available quantity of personnel', and 'management of the execution'.

3. We included a dummy variable for each municipality in order to control for unique municipal conditions (not reported in this table). These control variables were only in a small number of cases significant.

4. Ordinal variable: ' 1 ', municipalities with less than 20.000 inhabitants; ' 2 ', municipalities with 20.000 - 40.000 inhabitants; '3', municipalities with 40.000 - 100.000 inhabitants; '4', municipalities with more than 100.000 inhabitants.

* / ** / *** significant at $\mathrm{p}<0.10 / 0.05 / 0.01$.

The models show that the efficiency-motive is significantly positively related to contracting out decisions. Hence, municipalities expect external service providers - both private as public - to be more efficient. The quality-motive seems not to be relevant. The public private ideology-motive is negatively related to the decision to contract out, in particular to the private sector. Therefore, in case municipalities use this motive, this is, in general, used in favour of especially public or in house supply. The model does not give support to the relevance of institutional motives. This may be due to the fact that these motives are heterogeneous as a number of these institutional arguments are used in favour of public supply - as 'local employment' and 'influence on task execution' - and other are used in favour of contracting out - as ‘independence’ and ‘stability of service provision’. 
Besides, a number of motives - as 'core tasks' and 'availability of alternatives' are used in favour of contracting out by a number of interviewees, while other municipal managers use these motives against. However, an additional factor analysis showed that it was not possible to divide this category of institutional motives in a proper way. ${ }^{13}$ Finally, the pragmatic motives have a significant positive relationship with contracting out, also to the private sector. This conclusion is in accordance with Bel and Fageda (2007) who find that pragmatic reasons are relevant for contracting out decisions. Only for the control variable 'political constellation' we find a significant relationship. Left-wing municipalities are more in favour of self-supply than right-wing municipalities.

\section{Discussion and conclusions}

For this study, we interviewed 17 municipal executives, responsible for the management of the municipal organisation to discuss the causes and motives for the choice of the current structure for the delivery of their services. This offered the opportunity to explore institutional aspects of contracting out and it shows that institutional theory might contribute to understand contracting out decisions of municipalities. Especially the stability of service provision, quality differences between internal and external service providers and choices between internal and external focused tasks need further investigation.

Despite the potential motives for contracting out, the mode of service provision is, in general, not a managerial or political issue. Municipalities do not regularly evaluate their organisational performance and the cost and quality of their service provision. In fact, if the activity shows an adequate performance without complaints about, for example, the quality, a cause for this consideration is in general lacking. However, in case of structural underperformance or complaints about the performance or the quality of the activities, the execution of tasks becomes a topic for evaluation and a change of service provider is considered or implemented. This shows the relevance of institutional pressures in contracting out decisions. Besides, institutional changes, as the introduction of new legislation, decentralisation of tasks, or the building of new accommodation may be an opportunity for considering contracting out. However, as far as we can observe, in most cases a merger of municipalities is not a relevant moment for changing the mode of service provision.

As we conclude, the lack of a cause for considering contracting out is an important explanation for the in house provision of services. This may be an additional

\footnotetext{
${ }^{13}$ Due to the number of institutional motives (6) and the number of interviews, it was not possible to include these motives separately in this statistical analysis.
} 
explanation for the fact that the explanatory power of previous empirical studies is in general low (Bel and Fageda, 2007).

The interviews are used both to investigate the public choice theory and transaction costs hypotheses as to investigate the relevance of institutional concepts as well. The interviews show that the efficiency-motive is the most relevant aspect. Other studies explain the relevance of this motive by the empirical relationship between contracting out and use of municipal characteristics as size and the financial position of the municipality. These studies suppose that due to scale effects, smaller municipalities have more incentives to benefit from contracting out. However, the relevance of this motive does not seem to depend on the size of the municipality. For smaller municipalities, motives as, for example, the stability of their service provision, and the quality of external providers are far more relevant. Therefore, these motives might be better explanations for the suggested negative relationship between size and outsourcing in some empirical studies (compare Bel and Fageda, 2007).

The public private ideology-motive is relevant for decisions on contracting out. Left-wing municipalities say they are less prone for contracting out their service delivery, especially to private parties. In addition, in some municipalities we find that the private ideological opinion of strong local politicians or managers about the positive consequences of contracting out might be relevant as well. We do not find evidence for the political patronage motive as hypothesized by public choice theory (e.g. Dijkgraaf et al., 2003).

With respect to transaction cost theory, we find support for the service measurability hypothesis as activities with high service measurability have a higher chance of being contracted out, especially to the private sector. However, the interviewees do not consider the potential transaction costs of contracting - as for example the making of contracts and the monitoring of service execution - and asset specificity to be relevant. On the other hand, we find that activities with higher asset specificity have higher chance to be contracted out to a public service provider, as an intermunicipal corporation.

In case of contracting out, municipalities have different motives to choose for public or private execution of these tasks. In general, the efficiency-motive and the quality of service provision are leading. Some managers prefer contracting out to a private party for getting to grips, other explain that service provision by a public organisation provides more opportunity for management of the execution.

The interviews provided the opportunity to explore the relevance of other more institutional motives in contracting out decisions. Consistently with Wassenaar et al. (2010), according to the interviewees more institutional motives as the independence of external providers, the availability of alternatives, the stability of service provision, and 
the legal status and retirement decisions of municipal employees - play a role in considering contracting out. Especially for smaller municipalities, the stability of service provision is relevant. Nevertheless, we do not find statistical significant results for these variables. Besides, we see the relevance of more pragmatic-organizational motives as the available quantity and quality of personnel in the own organization, especially for the smaller municipalities.

As we conclude, the efficiency-motive is relevant for decision-making, although

municipalities need to have a catalyst to start evaluating the mode of service provision or decide for contracting out. As the coming years the financial position of most municipalities will deteriorate due to the consequences of the financial crisis, more municipalities might have an incentive to start a discussion on the actual mode of their service provision. Therefore, it would be relevant to investigate whether the lagging development of their budgets is a relevant institutional momentum and leads to an increase of contracting out of municipal activities.

\section{References}

Allers, M.A., C. Hoeben, L.A Toolsema and A.S. Zeilstra, (2008), Atlas van de lokale lasten 2008, Groningen, Coelo

Ashworth, R., G. Boyne and R. Delbridge (2007), 'Escape from the iron cage? Organizational change and isomorphic pressures in the public sector', Journal of Public Administration Research 19:165-187

Bel, G. and A. Miralles (2003), 'Factors influencing privatization of urban solid waste collection in Spain', Urban Studies 40: 1323-1334

Bel, G. and X. Fageda (2007), 'Why do local governments privatise public services? A survey of empirical studies’, Local Government Studies 33(4): 517-534

Bel, G., R. Hebdon and M.E. Warner (2007), 'Local government reform: Privatisation and its alternatives', Local Government Studies 33(4): 507-515

Bel, G. and Warner, M.E. (2008), 'Challenging issues in local privatisation', Environment and Planning C: Government and Policy 26(1): 104-109

Bogt, H.J. ter (2008), 'Recent and future management changes in local government: Continuing focus on rationality and efficiency?', Financial Accountability \& Management 24(1):31-57

Boyne, G.A. (1998a), Public choice theory and local government: a comparative analysis of the UK and the USA. New York, NY: St. Martin's Press

Boyne, G.A. (1998b), 'The determinants of variations in local service contracting: Garbage in, garbage out?', Urban Affairs Review 34(1):150-163 
Brignall, S. and S. Modell (2000), 'An institutional perspective on performance management and management in the 'new public sector', Management Accounting Research, 11:281-306.

Brown, T. and M. Potoski (2003), 'Transaction costs and institutional explanations for government service decisions', Journal of Public Administration Research and Theory 13:441-468

Brown, T. and M. Potoski (2005), 'Transaction costs and contracting. The practitioner perspective', Public Performance \& Management Review 28(3):326 - 351

Brown, T.L., M. Potoski and D.M. Van Slyke (2008), 'Changing modes of service delivery: how past choices structure future choices', Environment and Planning C: Government and Policy 26:127-143

Brudney, J.L., S. Fernandez, J. Eungha Ryu and D.S. Wright (2004), 'Exploring and Explaining contracting out: Patterns among the American states', Journal of Public Administration Research and Theory 15(3):393-419

Dacin, M.T., J. Goodstein and W.R. Scott (2002), 'Institutional theory and institutional change: Introduction to the special research forum', Academy of Management Journal 45(1):45-57

Dijkgraaf, E. and R.H.J.M. Gradus (2003), 'Cost savings of contracting out refuse Collection', Empirica 30:149-161

Dijkgraaf, E., R.H.J.M. Gradus and B. Melenberg (2003), 'Contracting out refuse collection’, Empirical Economics 28:553-570.

Domberger, S. and P. Jensen (1997), 'Contracting out by the public sector', Oxford Review of Economic Policy 13(4):67-78

Groot, T.L.C.M. and K. Lukka (2000), 'Introduction’, in: Groot, T.L.C.M. and K. Lukka (eds.), Cases in management accounting, Current practices in European companies, Harlow, Prentice Hall/Pearson

Hart, O., A. Shleifer and R. Vishny (1997), 'The proper scope of government: theory and applications to prisons', Quarterly Journal of Economics 112:1127-1161

Hebdon, R. and P. Jalette (2008), 'The restructuring of municipal services: A Canada United States comparison', Environment and Planning C: Government and Policy, 26(1):144-158

Hendriks, F. and P. Tops (2003), 'Local public management reforms in the Netherlands: facts, fashions and winds of change’, Public Administration, 81(2):301-323

Hodge, G. (2000), Privatisation. An international review of performance. Boulder, CO: Westview Press

Innes, J. and F. Mitchell (1990), The process of change in management accounting: some field study evidence', Management Accounting Research, 1: 3-19 
Joassart-Marcelli P. and J. Musso (2005), 'Municipal service provision choices within a metropolitan area', Urban Affairs Review 40(4):492-519

Johansson, P., L. Hall, S. Sikstrom and A. Olsson (2005), 'Failure to detect mismatches between intention and outcome in a simple decision task', Science, 310:5745, 116199.

Lopez-de-Silanes, F., A. Shleifer A. and R.W. Vishny (1997), 'Privatisation in the United States', Rand Journal of Economics 28: 447-471

Lounsbury, M. (2008), 'Institutional rationality and practice variation: new directions in the institutional analysis of practice', Accounting, Organization and Society 33:349361

Modell, S. (2009), 'Institutional research on performance measurement and management in the public sector accounting literature: A review and assessment', Financial Accountability and Management 25(3):277-303

Niskanen, W. (1971), Bureaucracy and representative government, Chicago, Aldine

Oliver, C. (1992), 'The antecedents of de-institutionalization', Organization Studies, 13, 563-88

Shleifer, A. (1998), 'State versus private ownership’, Journal of Economic Perspectives 12(4):133-150

Scott, W.R., (2008), 'Approaching adulthood: the maturing of institutional theory', Theory and Society 37:427-442

Szymanski, S. (1996), 'The impact of compulsory competitive tendering on refuse collection services', Fiscal Studies 17, 1-19

Tang, K.L. (1997), 'Efficiency of the private sector: a critical review of empirical evidence from public services', International Review of Administrative Sciences 63: 459-474

Warner, M.E. and A. Hefetz (2002), 'Applying market solutions to public services: an assessment of efficiency, equity and voice, Urban Affairs Review 38(1): 70 - 89

Wassenaar, M.C. and R.H.J.M. Gradus (2004), 'Contracting Out: The Importance of a Solution for the VAT Distortion’, CESifo Economic Studies 50(2): 377-396

Wassenaar, M.C., E. Dijkgraaf and R.H.J.M. Gradus (2010), 'Contracting out: Municipalities reject the solution for the VAT-distortion', Local Government Studies 36(5): 617-636

Warner, M.E. and R. Hebdon (2001), ‘Local government restructuring: privatisation and its alternatives', Journal of Policy Analysis and Management, 20(2): 315 - 336

Williamson, O.E. (1981), 'The economics of organization', American Journal of Sociology, 87:548-577 


\section{Appendix A Interviewed municipalities and their characteristics}

\begin{tabular}{|c|c|c|c|c|}
\hline & & $\begin{array}{l}\text { Number of } \\
\text { inhabitants } \\
\end{array}$ & $\begin{array}{l}\text { Level } \\
\text { of local } \\
\text { taxes }\end{array}$ & $\begin{array}{l}\text { Political } \\
\text { indicator }^{\mathrm{e}}\end{array}$ \\
\hline \multicolumn{5}{|c|}{ High local taxes / Left-wing } \\
\hline $100.000+$ & Groningen & 182.484 & 680 & 1,0 \\
\hline 40.000-100.000 & Leeuwarden & 92.684 & 664 & 0,8 \\
\hline $20.000-40.000$ & IJsselstein & 34.059 & 697 & 0,8 \\
\hline 20.000- & Oostzaan & 9.205 & 704 & 1,0 \\
\hline \multicolumn{5}{|c|}{ Low local taxes / Left-wing } \\
\hline $100.000+$ & Amersfoort & 141.211 & 600 & 0,5 \\
\hline 40.000-100.000 & Heerenveen & 43.027 & 625 & 0,8 \\
\hline $20.000-40.000$ & Hoogezand-Sappemeer & 34.417 & 607 & 0,8 \\
\hline 20.000- & Zijpe & 11.512 & 605 & 0,5 \\
\hline \multicolumn{5}{|c|}{ High local taxes / right-wing } \\
\hline $100.000+$ & Westland $^{\mathrm{a}}$ & 99.299 & 673 & 0,0 \\
\hline $40.000-100.000$ & Lelystad & 73.063 & 694 & 0,4 \\
\hline $20.000-40.000$ & Krimpen aan den IJssel & 28.907 & 775 & 0,3 \\
\hline \multirow[t]{2}{*}{$20.000-$} & Midden-Delfland $^{\mathrm{C}}$ & 17.451 & 789 & 0,0 \\
\hline & Rijnwoude & 18.704 & 669 & 0,3 \\
\hline \multicolumn{5}{|c|}{ Low local taxes / right-wing } \\
\hline $100.000+$ & Zwolle & 116.365 & 597 & 0,5 \\
\hline $40.000-100.000$ & Purmerend & 78.434 & 502 & 0,3 \\
\hline $20.000-40.000$ & Nunspeet & 26.567 & 522 & 0,0 \\
\hline $20.000-$ & Breukelen $^{\mathrm{d}}$ & 14.657 & 644 & 0,0 \\
\hline
\end{tabular}

a. The municipality of Westland was established in 2004.

b. The municipality of Krimpen aan den Ijssel is discussing potential mergers with surrounding municipalities

b. The municipality of Midden Delfland was established in 2004.

d. The municipality of Breukelen will merge in 2011 with 2 other municipalities.

e. We counted the relative number of aldermen with a membership of one of the left-wing parties (socialist party, green left and the labour party) in April 2009 (three years after the last municipal elections). In case this indicator comes at 50 percent, the relative number of left-wing members of the municipal council is decisive. 


\section{Appendix B Interviewprotocol}

\section{A. Question 1}

Which five motives are in general the most relevant in discussions about contracting out activities to a public or private organisation? Do these motives have a positive or a negative impact? Can you give the motives one of the following qualifications: 'very important', 'important', 'neutral', 'unimportant', 'very unimportant'? Please provide an explanation to these answers.

\begin{tabular}{|l|l|l|l|}
\hline Motive & Positive or negative & $\begin{array}{l}\text { Relevance of the } \\
\text { motive }^{1}\end{array}$ & Explanation \\
\hline 1. & & & \\
\hline 2. & & & \\
\hline 3. & & & \\
\hline 4. & & & \\
\hline 5. & & & \\
\hline
\end{tabular}

1. 'Very important', 'important', 'neutral', 'unimportant', 'very unimportant'

\section{B. Question 2}

In this question, we discuss some motives as provided by previous studies as being potentially relevant in considering contracting out. Please give an answer to the following questions:

- Does this motive have a positive or negative impact on the discussion on contracting out?

- Can you give the motives one of the following qualifications: 'very important', 'important', 'neutral', 'unimportant', 'very unimportant'.

- Please provide an explanation to these answers. 


\begin{tabular}{|c|c|c|c|}
\hline Motive & $\begin{array}{l}\text { Positive } \\
\text { or nega- } \\
\text { tive }\end{array}$ & $\begin{array}{l}\text { Importance } \\
\text { of the } \\
\text { motive }^{1}\end{array}$ & Explanation \\
\hline \multicolumn{4}{|l|}{ Efficiency; the lower costs of external service provision } \\
\hline \multicolumn{4}{|l|}{ Quality; the higher quality of external service provision } \\
\hline \multicolumn{4}{|l|}{$\begin{array}{l}\text { Independence of external providers; the independence of external providers from } \\
\text { the municipal organisation }\end{array}$} \\
\hline \multicolumn{4}{|l|}{$\begin{array}{l}\text { Political patronage; the influence of local interested parties, as lobby groups, } \\
\text { labour organisations or the local businesses }\end{array}$} \\
\hline \multicolumn{4}{|l|}{$\begin{array}{l}\text { Local employment; concern for employment in the municipality itself, especially } \\
\text { for the organisations for sheltered employment }\end{array}$} \\
\hline \multicolumn{4}{|l|}{$\begin{array}{l}\text { Public private ideology; opinion of the role of the government in comparison with } \\
\text { the market }\end{array}$} \\
\hline \multicolumn{4}{|l|}{$\begin{array}{l}\text { Availability of expertise in the own organisation; the availability of expertise and } \\
\text { quality in the own organisation as needed for an adequate service level. }\end{array}$} \\
\hline \multicolumn{4}{|l|}{$\begin{array}{l}\text { Optimal scale of the municipal organisation; the optimal scale of the municipal } \\
\text { organisation (in general, number of employees) or the adequate level of the } \\
\text { municipality (number of inhabitants) for an acceptable service level. }\end{array}$} \\
\hline \multicolumn{4}{|l|}{$\begin{array}{l}\text { Core tasks; core tasks as defined by the municipality itself (tasks that should not } \\
\text { be contracted out, due to the municipal responsibility). }\end{array}$} \\
\hline \multicolumn{4}{|l|}{$\begin{array}{l}\text { Flexibility; the flexible design of the municipal organisation, because of the lack } \\
\text { of a constant level of work. }\end{array}$} \\
\hline \multicolumn{4}{|l|}{$\begin{array}{l}\text { Available quantity of personnel; the availability of enough personnel for an } \\
\text { adequate service level. }\end{array}$} \\
\hline \multicolumn{4}{|l|}{ Risk avoidance; the desire to avoid risk in the provision of services. } \\
\hline \multicolumn{4}{|l|}{ Stability; the stability of service provision } \\
\hline \multicolumn{4}{|l|}{$\begin{array}{l}\text { Transaction costs; transaction costs that come with the process of contracting, as } \\
\text { costs of planning, adapting, and monitoring. }\end{array}$} \\
\hline \multicolumn{4}{|l|}{$\begin{array}{l}\text { Costs of actives; the relatively high costs of investments that have to be made for } \\
\text { the service provision. }\end{array}$} \\
\hline \multicolumn{4}{|l|}{$\begin{array}{l}\text { Experiences in other municipalities; positive or negative experiences of other } \\
\text { municipalities with contracting out. }\end{array}$} \\
\hline \multicolumn{4}{|l|}{$\begin{array}{l}\text { Availability of alternatives; the availability of more then one external service } \\
\text { provider. }\end{array}$} \\
\hline $\begin{array}{l}\text { VAT-compensation fund; the opportunities as arisen with the introduction with } \\
\text { the VAT-compensation fund in } 2003 .\end{array}$ & & & \\
\hline
\end{tabular}

1. 'Very important', 'important', 'neutral', 'unimportant', 'very unimportant'

\section{Question 3}

Name three municipal activities that have recently been contracted out, or will be contracted out in the near future, or are discussed to be contracted out to a public or private organization?

What are for these three activities the motives for contracting out or not? You can use the same motives as for questions 1 and 2, or additional motives. 


\begin{tabular}{|c|c|c|c|}
\hline Activity & Positive or negative & $\begin{array}{l}\text { Relevance of the } \\
\text { motive }^{1}\end{array}$ & Explanation \\
\hline \multicolumn{4}{|c|}{ Activity 1 - 3} \\
\hline \multicolumn{4}{|l|}{ - Motive 1} \\
\hline \multicolumn{4}{|l|}{ - Motive 2} \\
\hline - Motive 3 & & & \\
\hline
\end{tabular}

1. 'Very important', 'important', 'neutral', 'unimportant', 'very unimportant'

Which type of organization did you chose, or will you chose probably?

For activity $1-3$ :

Public / private

Motive:

\section{Question 4}

Finally, we discuss the actual mode of service provision for ten standard activities. As far as for these activities a combination of mode is chosen, I will discuss the most relevant. The question is asked for the following activities:

\begin{tabular}{|l|l|l|}
\hline Activity & Activity nr. $\mathrm{I}^{1}$ \\
\hline Self supply O & Publicly contracted out O & Privately contracted out O \\
\hline & & \\
\hline Motive 1 (most important) & motive & Explanation \\
\hline $\begin{array}{l}\text { Motive 2 (second most } \\
\text { important) }\end{array}$ & & \\
\hline Motive 3 (third most important) & & \\
\hline
\end{tabular}

1. This question is asked for the following activities: (1) cleaning services, (2) canteen services, (3) security, (4) payroll administration, (5) IT-services, (6) social services, (7) refuse collection, (8) small infrastructure works, (9) valuation of real estate, and (10) park management. 


\section{Appendix C Statistical results}

This appendix provides the integral statistical analysis as described in section 5.3.

Table B.1 Mode of service provision and motives

\begin{tabular}{|c|c|c|}
\hline & $\begin{array}{l}\text { Model A: Public or private } \\
\text { contracting out }=1 \text {, self } \\
\text { supply }=0\end{array}$ & $\begin{array}{l}\text { Model B: Private } \\
\text { contracting out }=1 \text {, self } \\
\text { supply or public } \\
\text { contracting out }=0 \\
\end{array}$ \\
\hline Efficiency & $2.183(0.535) * * *$ & $1.539(0.428) * * *$ \\
\hline Quality of external service provision & $1.017(0.638)$ & $0.781(0.520)$ \\
\hline Political-ideological motives ${ }^{1}$ & $-1.548(0.938) *$ & $-2.511(0.936) * * *$ \\
\hline Institutional motives $^{2}$ & $0.583(0.399)$ & $-0.149(0.369)$ \\
\hline Pragmatic motives $^{3}$ & $1.384(0.449) * * *$ & $0.905(0.349) * * *$ \\
\hline Number of inhabitants & $-0.593(0.470)$ & $-0.294(0.361)$ \\
\hline $\begin{array}{l}\text { Political constellation, left-wing = } \\
\text { ' } 1 \text { ' }\end{array}$ & $-3.427(1.839) *$ & $-0.753(1.473)$ \\
\hline $\begin{array}{l}\text { Level of local tax rate, high taxes = } \\
\text { ' } 1 \text { ' }\end{array}$ & $-1.297(1.147)$ & $-0.098(1.056)$ \\
\hline Amersfoort & $4.043(1.851) *$ & $2.406(1.487)$ \\
\hline Breukelen & $-0.619(1.932)$ & $0.332(1.482)$ \\
\hline Groningen & $4.562(2.461) *$ & $2.123(2.111)$ \\
\hline Heerenveen & $1.685(1.561)$ & $0.797(1.286)$ \\
\hline Hoogezand-Sappemeer & $4.389(1.615) * * *$ & $1.901(1.264)$ \\
\hline IJsselstein & $2.847(1.846)$ & $0.849(1.641)$ \\
\hline Krimpen aan den IJssel & $2.847(1.846)$ & $0.933(0.921)$ \\
\hline Leeuwarden & $2.941(2.133)$ & $0.531(1.858)$ \\
\hline Lelystad & $0.960(1.073)$ & $1.469(0.995)$ \\
\hline Midden-Delfland & $-1.299(1.371)$ & $-0.710(1.017)$ \\
\hline Nunspeet & $-1.919(1.444)$ & $0.262(1.246)$ \\
\hline Oostzaan & $-2.489(1.654)$ & $-0.984(1.530)$ \\
\hline Purmerend & $-1.463(1.185)$ & $0.098(1.081)$ \\
\hline Rijnwoude & \multirow{4}{*}{\multicolumn{2}{|c|}{$\begin{array}{l}\text { Due to redundancies, the model did not give results for } \\
\text { these municipal dummy variables }\end{array}$}} \\
\hline Westland & & \\
\hline Zijpe & & \\
\hline Zwolle & & \\
\hline Constant & $1.993(2.077)$ & $-0.119(1.663)$ \\
\hline -2 Log likelihood & 163.391 & 190.870 \\
\hline Cox \& Snell R ${ }^{2}$ & 0.301 & 0.231 \\
\hline Nagelkerke $\mathrm{R}^{2}$ & 0.410 & 0.308 \\
\hline
\end{tabular}

1. The motives 'political patronage' and 'public private ideology'.

2. The motives 'local employment', 'core tasks', and 'influence on task execution', 'independence of external service providers', 'stability’, ‘availability of alternatives’.

3. The motives 'availability of expertise in the own organization', 'flexibility', 'available quantity of personnel', and 'management of the execution'.

$*$ / ** / *** significant at $\mathrm{p}<0.10 / 0.05 / 0.01$. 